\title{
TIME SCHEDULING AND COST OF THE INDONESIAN NAVY SHIP DEVELOPMENT PROJECT USING NETWORK DIAGRAM AND EARNED VALUE METHOD (EVM) (CASE STUDY OF FAST MISSILE BOAT DEVELOPMENT)
}

\author{
Ahmadi $^{1}$, Suparno ${ }^{2}$, Okol Sri Suharyo ${ }^{3}$, Arica Dwi Susanto ${ }^{4}$ \\ 1,3,4 Indonesian Naval Technology College, STTAL. \\ Bumimoro-Morokrembangan, Surabaya 60187, Indonesia \\ 2 Sepuluh Nopember Institute of Technology, ITS \\ Raya ITS, Keputih, Sukolilo, Surabaya 60111, Indonesia
}

\begin{abstract}
Missile Boat is one of Indonesian Navy Warship (KCR-60) which has a length of 60 meters and made domestically by Indonesian people at the PT. $X$ in Surabaya. Time delay and cost overruns are the problems in the Missile Boat construction project (KCR-60). The purpose of this research was to schedule the time and cost of the project so that it can be completed on time and there is no swelling of costs for the implementation of the construction of the Missile Boats (KCR-60). The scheduling method used in this study was Precedence Diagram Method (PDM) on Network Diagram and Earned Value Method (EVM). Precedence Diagram Method (PDM) was used for scheduling the project time and showing the critical trajectory of project activities along with the acceleration time (Crashing Project) while Earned Value Method (EVM) was used to determine the costs and time performance and the factors that cause delays or progress of the project. The results showed that the project schedule had 13 activities that had a zero slack or critical activities which were in activities 1, 2, 3, 4, 5, $6,16,18,21,23,26,27,28$. There acceleration of time (Crashing Project) by adding hours of work or overtime for 1 hour every day to 21 activities $(1,2,3,4,5,6,7,8,9,10,11,12,13,14,15,16,17,18,19)$ will accelerate and reduce the duration of project completion, which was originally 414 days from the completion of the actual work of implementation to 363 days, thus the difference of effectiveness was 51 days (more effective). Meanwhile, for cost efficiency, based on the analysis of the real cost of project implementation, the amount of Idr. 20.407,094,998, - became Rp. 18,410,738,982, thus it became more efficient by Idr. 2,470,548,998, -.
\end{abstract}

Keywords: Network Diagram, PDM, Crashing Project, EVM, KCR-60.

\section{INTRODUCTION.}

Fast Missile Boat is one of Indonesian Navy Warship (KCR-60) which has a length of 60 meters and made domestically by Indonesian people at the PT. $X$ in Surabaya which engaged in the production of warships and commercial vessels, providing ship repair and maintenance services as well as general engineering with order-based specifications (Silvianita, 2018).

Along with the development of the technology industry, ship production requires every shipyard to evaluate the system used. The new shipbuilding project is required to work fast according to the schedule. Poor performance, low quality, and cost overruns often occur in a project (Arica Dwi Susanto, 2018).

The delay is caused by several factors, namely: the limited number of local workers, the ineffectiveness of the use of subcontractors due to lack of firmness to subcontractors who work beyond the schedule and are less selective in choosing subcontractors, delays in material ordering, 
damage to shipyard machinery, lack of better technology to support the process, unpredictable weather factors, and several other unexpected factors.

The literature used in this paper were obtained to support the research. This literature includes a paper titled A fuzzy pert approach to evaluate plant construction project scheduling risk under uncertain resources capacity (R.Lin, 2009). Earned Value Management Systems: Challenges and Future Direction (Wilson, 2013). CPM, PERT and Project Management With Fuzzy Logic Technique and Implementation On A Business (Mazlum, 2015). Integration of Building Information Modeling and Critical Path Method Schedules to Simulate the Impact of Temperature and Humidity at the Project Level (Shan, 2014). Comparative Study of Management Operation System Techniques (MOST) and CPM in Construction Scheduling (Shailla, 2014). Extension of Time Determination in Construction Projects in Nigeria: The Critical Path Method (Andawei, 2014). Critical path analysis for the management of fractured neck of femur (Balla, 1995). The Critical Path Method In Estimating Project Duration (Nafkha, 2016). Critical Path Analysis for New Product Planning (Wong, 1964). Measuring the Actual Energy Cost Performance of Green Buildings: A Test of the Earned Value Management Approach (Dwaikat, 2016). Cost Control and Performance Review of Software Projects by Using the Earned Value Management (Alecu, 2014). Critical Path Method in Designing Feasible Solutions (Agarwal, 2013). Traditional Critical Path Method versus Critical Chain Project Management: A Comparative View (M, 2015). Project Planning And Control With Pert And Cpm (K.K.Khandelwal, 2002). Project Planning And Scheduling Using PERT And CPM Techniques With Linear Programming: Case Study (Agyei, 2015). Fast Missile Boat Project Planning using CPM and What If Analysis Method (Silvianita,
2018). CPM Schedule Summarizing Function of the Beeline Diagram Method (Kim, 2012). Earned value method as a tool for project control (Czarnigowska, 2008). The Factors Affecting The Methods of Construction Projects Scheduling: An State of The Art and Overview (Fatemeh Nouban, 2017). Construction Project Scheduling with Time, Cost

and Material Restrictions Using Fuzzy Mathematical Models and Critical Path Method (Daniel Castro-Lacouture, 2009). Planning and Monitoring of industrial punch development processes (Y. Arslan, 2017).

Network Diagram is in Precedence Diagram Method (PDM) and Earned Value Method (EVM) techniques. The Earned Value Method (EVM) is able to find deviations between plans and reality, and encourage to look for the causes. While the calculation technique of the Precedence Diagram Method (PDM) on the Network Diagram that we use has important advantages, which are: Project scheduling in the form of a network diagram shown by lines / arrows with a very clear dependency relationship and showing the critical path of project activities so that if there are project delays, the priority of project work to be corrected will be easy to do, and the solution is given if there is a time constraint, which is a Crashing Project.

This Paper is organized as follows. Section 2 review of the basic ship theory. Section 3 gives result and section 4 discussion of research. Finally, in section 5 present conclusion this paper.

\section{MATERIALS/METHODOLOGY.}

\subsection{Technical Concept}

This study used the Precedence Diagram Method (PDM) for scheduling the time of 60 meter ship development project and showing the critical trajectory of project activities and the acceleration of time by adding labor or Crashing Projects while the Earned Value Method (EVM) was used to 
determine the cost and time performance, as well as the factors that cause the delay or progress of the project.

\subsection{Network Diagram}

Networking is a tool used to plan, schedule, and control project progress. Stages of compiling a Network Diagram:

a. Inventory activities from the Work Breakdown Structure (WBS) package based on work items, then given an activation code to facilitate identification.

b. Estimating the duration of each activity by considering the type of work, work volume, number of resources, work environment, and worker productivity.

c. Determination of the logic of dependence between activities carried out with three possible relationships, namely predecessor activities, activities that are preceded (successors), and free.

d. Analysis calculation of time and location of resources, this would be performed after the steps above are carried out accurately and thoroughly.

\subsection{Network Component}

There are two approaches to describe the project network: activity on node - AON and activity on arrow (AOA). At the AON convention, the point indicates the activity, whereas at the AOA, the arrow indicates the activity.

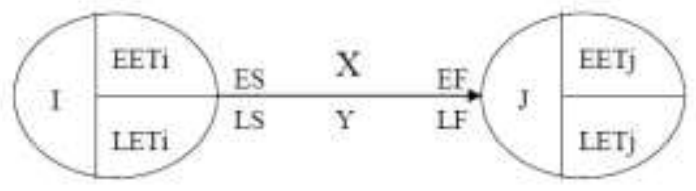

Fig. 1 Activity On Arrow

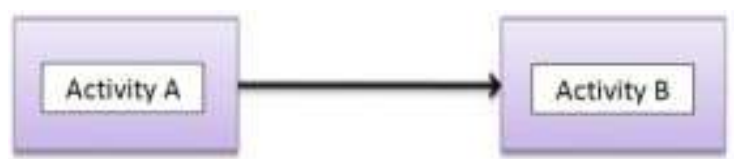

Fig. 2 Activity On Node

\subsection{Work Breakdown Structure (WBS)}

WBS is a method of organizing projects into hierarchical reporting structures. WBS is used to break down or solve each work process in more detail.

\subsection{Precedence Diagram Method (PDM)}

Precedence Diagram Method is a networking method that is included in the classification of AON (Activity On Node). In this method, the activity is written in a node that is generally rectangular, while the arrows as a pointer relationship between the activities concerned. Thus the dummy which is an important sign to indicate the dependence relationship, is not required in PDM.

On the precedence method, a diagram can be described as there are four relations of activity/logic, Each node has two ends, namely the beginning or beginning $=(S)$ and the end or end $=(F)$.

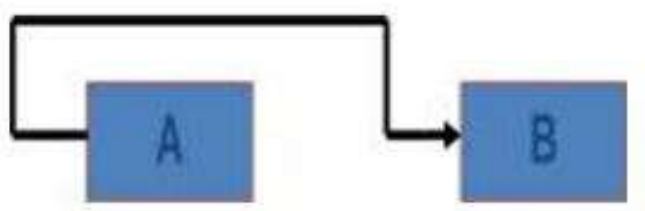

Fig. 3 Activity Relation of Start-to-Start (SS)

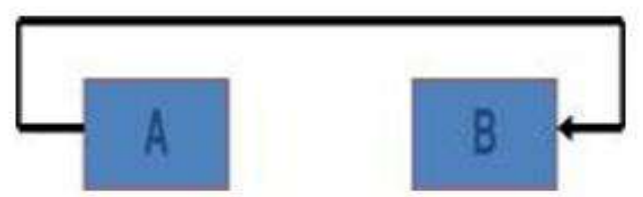

Fig. 4 Activity Relation of Start-to-Finish (SF)

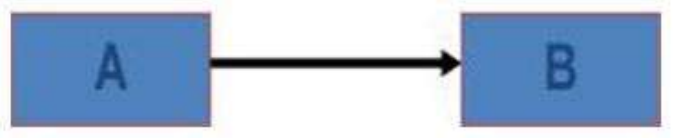

Fig. 5 Activity Relation of Finish-to-Start (FS) 


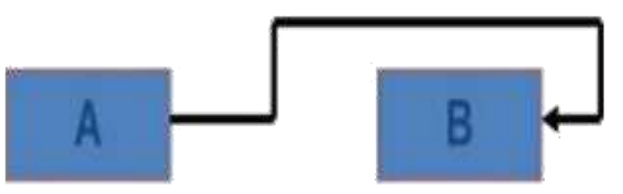

Fig. 6 Activity Relation of Finish-to-Finish (FF)

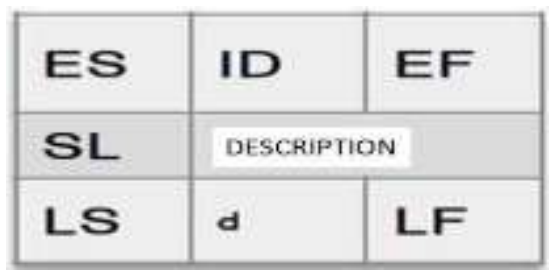

Fig. 7 Network Diagram PDM

\subsection{Crashing Project}

The method for shortening the length of project time by reducing the time of one or more so that the important project activities becomes less than the normal time of activity.

\subsection{Earned Value Method}

EVM is one of the tools used in project management that integrates cost and time by presenting three dimensions, namely the physical completion of the project (the percent complete) which reflects the budgeted cost, actual costs that have been incurred or what is called actual cost and what obtained from costs already incurred.

\subsection{Method of Research.}

This study uses Microsoft Project 2007 computer program for the analysis of Precedence Method Diagram and Earned Value Method analysis.
The instruments for analyzing Precedence Diagram Method are as follows:

a. Time Schedule of Missile Boats (KCR60) Development

b. Gantt Chart for the development of Missile Boats (KCR-60)

c. Budget Plan (RAB) for the development of Missile Boats (KCR-60)

d. Price of wages and materials.

The instruments for Earned Value Method analysis are described as follows:

a. S-Curve (Plan and Realization)

b. Employment / Budget Prices

c. Financial Report, in the form of actual costs incurred by the Contractor (Actual Costs).

\section{RESULT AND DISCUSSION.}

In this part, the authors would like to discuss about the critical path with PDM, Crashing Project for accelerating the time and cost with the EVM method, so that the time and costs are expected to be in accordance with the planning of the construction of Missile Fast Ships (KCR-60).

\section{1. object Time Planning Data}

Time planning data for the Missile Fast Ship construction project (KCR-60) for 363 days. The data on the schedule of the Missile Fast Ship development planning project (KCR-60) along with the duration of the project are listed in the table below:

Table 1. Schedule and Duration of the 60 Meter Ship Construction Project

\begin{tabular}{|c|l|c|c|c|}
\hline No & \multicolumn{1}{|c|}{ Activity } & $\begin{array}{c}\text { Duration } \\
\text { (day) }\end{array}$ & Start & Finish \\
\hline & Hull Construction & & $10 / 10 / 2016$ & $06 / 06 / 2017$ \\
\hline 1 & Hull Fabrication & 70 & $10 / 10 / 2016$ & $15 / 01 / 2017$ \\
\hline 2 & Hull Sub Assembly & 104 & $18 / 10 / 2016$ & $11 / 03 / 2017$ \\
\hline 3 & Hull Assembly & 138 & $26 / 10 / 2016$ & $06 / 05 / 2017$ \\
\hline
\end{tabular}




\begin{tabular}{|c|c|c|c|c|}
\hline No & Activity & $\begin{array}{c}\text { Duration } \\
\text { (day) }\end{array}$ & Start & Finish \\
\hline \multirow[t]{2}{*}{4} & Hull Erection & 138 & $25 / 11 / 2016$ & $06 / 06 / 2017$ \\
\hline & $\begin{array}{l}\text { Painting anode Cathodic } \\
\text { Protection }\end{array}$ & & $01 / 10 / 2016$ & $22 / 05 / 2017$ \\
\hline 5 & $\begin{array}{l}\text { Blasting and Painting Raw } \\
\text { Material }\end{array}$ & 54 & $10 / 10 / 2016$ & $15 / 12 / 2016$ \\
\hline 6 & Block Blasting and Painting & 142 & 15/11/2016 & $31 / 05 / 2017$ \\
\hline 7 & Finishing Hull & 27 & $06 / 06 / 2017$ & $12 / 07 / 2017$ \\
\hline 8 & Painting Outfitting & 79 & $06 / 06 / 2017$ & $22 / 09 / 2017$ \\
\hline \multirow[t]{2}{*}{9} & Anode & 19 & $14 / 03 / 2017$ & $07 / 04 / 2017$ \\
\hline & Hull Outfitting & & $10 / 10 / 2016$ & 05/10/2017 \\
\hline 10 & Seat and Foundation & 87 & $10 / 10 / 2016$ & $07 / 02 / 2017$ \\
\hline 11 & Deck Machinery and Equipment & 87 & $07 / 02 / 2017$ & $07 / 06 / 2017$ \\
\hline \multirow[t]{2}{*}{12} & Interior & 173 & $07 / 02 / 2017$ & $05 / 10 / 2017$ \\
\hline & Machinery Outfitting & & $10 / 10 / 2016$ & 05/10/2017 \\
\hline 13 & Piping System Including Ducting & 182 & $10 / 10 / 2016$ & $20 / 06 / 2017$ \\
\hline 14 & Shafting & 52 & $20 / 06 / 2017$ & $30 / 08 / 2017$ \\
\hline \multirow[t]{2}{*}{15} & Machinery Outfitting & 26 & $31 / 08 / 2017$ & $05 / 10 / 2017$ \\
\hline & Electric, Electronic Outfitting & & $10 / 10 / 2016$ & $05 / 10 / 2017$ \\
\hline 16 & Cabling & 173 & $10 / 10 / 2016$ & $07 / 06 / 2017$ \\
\hline 17 & Power Supply & 173 & $02 / 11 / 2016$ & $01 / 07 / 2017$ \\
\hline 18 & Illumination & 173 & $26 / 11 / 2016$ & $26 / 07 / 2017$ \\
\hline 19 & $\begin{array}{l}\text { Communication and } \\
\text { Instrumentation }\end{array}$ & 179 & $21 / 12 / 2016$ & $18 / 08 / 2017$ \\
\hline 20 & Computing and Information & 173 & 13/01/2017 & $12 / 09 / 2017$ \\
\hline \multirow[t]{2}{*}{21} & Nautical and Radio & 173 & $07 / 02 / 2017$ & $05 / 10 / 2017$ \\
\hline & Function and Commisioning & & $05 / 10 / 2017$ & $30 / 10 / 2017$ \\
\hline 22 & Machinery Commisioning & 10 & $05 / 10 / 2017$ & $18 / 10 / 2017$ \\
\hline 23 & Equipment Commisioning & 9 & 10/10/2017 & $21 / 10 / 2017$ \\
\hline 24 & Lighting commisioning & 5 & $18 / 10 / 2017$ & $24 / 10 / 2017$ \\
\hline \multirow[t]{2}{*}{25} & System Control Commisioning & 5 & $24 / 10 / 2017$ & $30 / 10 / 2017$ \\
\hline & HAT and SAT & & $02 / 11 / 2017$ & $18 / 12 / 2017$ \\
\hline 26 & Harbour Acceptance Test & 32 & $02 / 11 / 2017$ & $16 / 12 / 2017$ \\
\hline \multirow[t]{2}{*}{27} & Yard Trial & 15 & $27 / 11 / 2017$ & $18 / 12 / 2017$ \\
\hline & Delivery & & $20 / 12 / 2017$ & $20 / 12 / 2017$ \\
\hline 28 & Delivery to Customer & 0 & $20 / 12 / 2017$ & $20 / 12 / 2017$ \\
\hline
\end{tabular}

\subsection{Project Cost Planning Data}

The project cost budget is very important in the Missile Boat (KCR-60) construction project. After the contractor designed the time planning data for the Missile Boat construction project (KCR-

60 ), the contractor also carried out a project cost budget plan based on existing market experience and prices. The Budget Plan (RAB) is listed in the table below: 
Table 2. Budget planning

\begin{tabular}{|c|c|c|c|c|}
\hline No. & \multicolumn{2}{|r|}{ Job Description } & \multicolumn{2}{|c|}{ Cost } \\
\hline \multirow[t]{5}{*}{ A } & \multicolumn{2}{|c|}{ Hull Construction } & & \\
\hline & 1 & Hull Fabrication & $\mathrm{Rp}$ & 502.424 \\
\hline & 2 & Hull Sub Assembly & $\mathrm{Rp}$ & 746.459 \\
\hline & $\overline{3}$ & Hull Assembly & $\mathrm{Rp}$ & 990.494 \\
\hline & 4 & Hull Erection & $\mathrm{Rp}$ & 990.494 \\
\hline \multirow[t]{6}{*}{ B } & \multicolumn{2}{|c|}{ Painting anode Cathodic Protection } & & \\
\hline & 5 & Blasting and Painting Raw Material & $\mathrm{Rp}$ & 387.584 \\
\hline & 6 & Block Blasting and Painting & $\mathrm{Rp}$ & 1.019 .203 \\
\hline & 7 & Finishing Hull & $\mathrm{Rp}$ & 193.792 \\
\hline & 8 & Painting Outfitting & $\mathrm{Rp}$ & 567.022 \\
\hline & 9 & Anode & $\mathrm{Rp}$ & 136.372 \\
\hline \multirow[t]{4}{*}{$\mathbf{C}$} & \multicolumn{2}{|c|}{ Hull Outfitting } & & \\
\hline & 10 & Seat and Foundation & $\mathrm{Rp}$ & 624.442 \\
\hline & 11 & Deck Machinery and Equipment & $\mathrm{Rp}$ & 624.442 \\
\hline & 12 & Interior & $\mathrm{Rp}$ & 1.241 .706 \\
\hline \multirow[t]{4}{*}{ D } & \multicolumn{2}{|c|}{ Machinery Outfitting } & & \\
\hline & $\overline{13}$ & Piping System Including Ducting & $\mathrm{Rp}$ & 1.306 .303 \\
\hline & 14 & Shafting & $\mathrm{Rp}$ & 373.229 \\
\hline & 15 & Machinery Outfitting & $\mathrm{Rp}$ & 186.615 \\
\hline \multirow[t]{7}{*}{$E$} & \multicolumn{2}{|c|}{ Electric, Electronic Outfitting } & & \\
\hline & 16 & Cabling & $\mathrm{Rp}$ & 1.220 .173 \\
\hline & 17 & Power Supply & $\mathrm{Rp}$ & 1.263 .238 \\
\hline & 18 & Illumination & $\mathrm{Rp}$ & 1.241 .706 \\
\hline & 19 & Communication and Instrumentation & $\mathrm{Rp}$ & 1.284 .771 \\
\hline & 20 & Computing and Information & $\mathrm{Rp}$ & 1.291 .948 \\
\hline & 21 & Nautical and Radio & $\mathrm{Rp}$ & 1.191 .463 \\
\hline \multirow[t]{5}{*}{$\bar{E}$} & \multicolumn{2}{|c|}{ Function and Commisioning } & & \\
\hline & $\overline{22}$ & Machinery Commisioning & $\mathrm{Rp}$ & 71.775 \\
\hline & 23 & Equipment Commisioning & $\mathrm{Rp}$ & 64.597 \\
\hline & 24 & Lighting commisioning & $\mathrm{Rp}$ & 35.887 \\
\hline & 25 & System Control Commisioning & $\mathrm{Rp}$ & 35.887 \\
\hline \multirow[t]{3}{*}{$\mathbf{F}$} & \multicolumn{2}{|c|}{ HAT and SAT } & & \\
\hline & 26 & Harbors Acceptance Test & $\mathrm{Rp}$ & 229.680 \\
\hline & 27 & Yard Trial & $\mathrm{Rp}$ & 107.662 \\
\hline \multirow[t]{3}{*}{$\mathbf{G}$} & \multicolumn{2}{|c|}{ Delivery } & & \\
\hline & 28 & Delivery to Customer & $\mathrm{Rp}$ & 7.177 \\
\hline & \multicolumn{2}{|c|}{ TOTAL } & Rp & 17.936.546 \\
\hline
\end{tabular}

\subsection{Gantt Chart Planning Project for Missile Boat Construction (KCR-60).}

The making of schedule plan for a Missile Boat (KCR-60) construction project used Gantt Chart to determine when the activities would be started, postponed and completed. The planned schedule of the Missile Boat construction project (KCR-60) can be seen in the following figure below: 


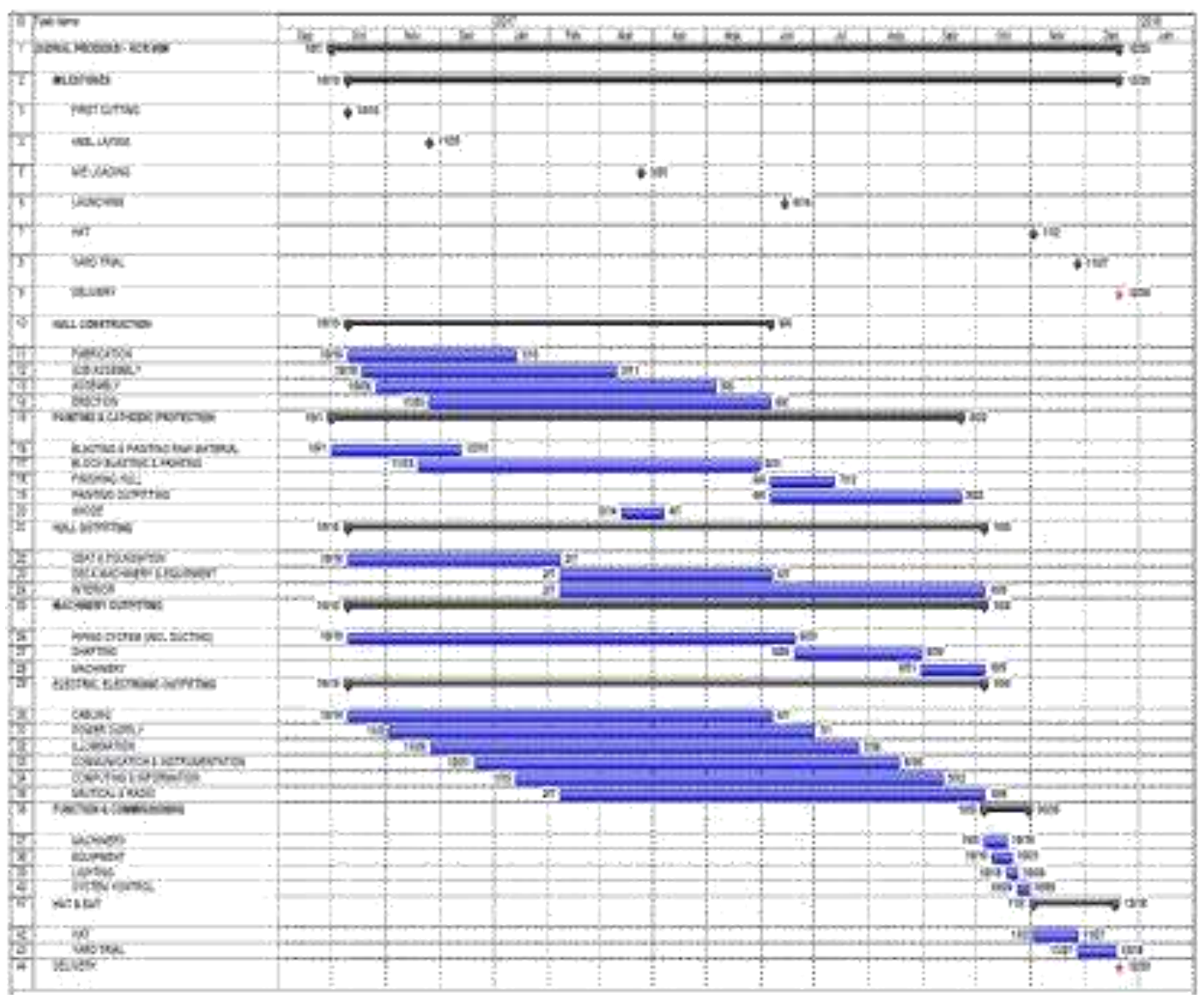

Fig. 8 Gantt Chart Planning Project for Missile Boat Construction (KCR-60).

\section{DISCUSSION.}

In this study, the PDM method used one determinant number and four constraints. The four constraints in the Precedence Diagram Method (PDM) are important components in the formation of its network. In addition, the four constraints gave different forms by placing activity information in the display of precedent diagrams as nodes.

The results of data processing for construction determination on the Missile Boat (KCR-60) construction project can be seen in the following table:

Table 3. Constraint Determination of Missile Boat (KCR-60) Construction Project

\begin{tabular}{|c|l|c|l|}
\hline No & \multicolumn{1}{|c|}{ Activity } & $\begin{array}{c}\text { Duration } \\
\text { (days) }\end{array}$ & \multicolumn{1}{|c|}{ Constraint } \\
\hline 1 & Hull Fabrication & 70 & - \\
\hline 2 & Hull Sub Assembly & 104 & $\mathrm{SS}(1-2)=8$ \\
\hline 3 & Hull Assembly & 138 & $\mathrm{SS}(2-3)=8$ \\
\hline 4 & Hull Erection & 138 & $\mathrm{SS}(3-4)=30$ \\
\hline 5 & Blasting and Painting Raw Material & 54 & - \\
\hline 6 & Block Blasting and Painting & 142 & $\mathrm{SS}(5-6)=40$ \\
\hline 7 & Finishing Hull & 27 & $\mathrm{FS}(9-7)=29$ \\
\hline & & & $\mathrm{FS}(3-7)=32$ \\
\hline
\end{tabular}




\begin{tabular}{|c|c|c|c|}
\hline No & Activity & $\begin{array}{c}\text { Duration } \\
\text { (days) }\end{array}$ & Constraint \\
\hline & & & $\mathrm{FS}(4-7)=0$ \\
\hline & & & $\mathrm{FS}(6-7)=6$ \\
\hline \multirow[t]{2}{*}{8} & Painting Outfitting & 79 & $\mathrm{FS}(4-8)=0$ \\
\hline & & & $\mathrm{FS}(6-8)=6$ \\
\hline 9 & Anode & 19 & $\mathrm{FS}(2-9)=3$ \\
\hline 10 & Seat and Foundation & 87 & - \\
\hline 11 & Deck Machinery and Equipment & 87 & $\mathrm{FS}(10-11)=0$ \\
\hline 12 & Interior & 173 & $\mathrm{FS}(10-12)=0$ \\
\hline 13 & Piping System Including Ducting & 182 & - \\
\hline \multirow[t]{2}{*}{14} & Shafting & 52 & $\mathrm{FS}(11-14)=13$ \\
\hline & & & $\mathrm{FS}(13-14)=0$ \\
\hline \multirow[t]{3}{*}{15} & Machinery Outfitting & 26 & $\mathrm{FS}(7-15)=27$ \\
\hline & & & $S S(8-15)=76$ \\
\hline & & & $\mathrm{FS}(14-15)=1$ \\
\hline 16 & Cabling & 173 & 0 \\
\hline 17 & Power Supply & 173 & $\mathrm{SS}(16-17)=22$ \\
\hline 18 & Illuminiation & 173 & $\mathrm{SS}(16-18)=49$ \\
\hline 19 & Communication and Instrumentation & 179 & $\mathrm{SS}(16-19)=72$ \\
\hline 20 & Computing and Information & 173 & $S S(16-20)=95$ \\
\hline 21 & Nautical and Radio & 173 & $S S(16-21)=120$ \\
\hline \multirow[t]{2}{*}{22} & Machinery Commisioning & 10 & $\mathrm{FS}(12-22)=0$ \\
\hline & & & $\mathrm{FS}(15-22)=0$ \\
\hline \multirow[t]{6}{*}{23} & Equipment Commisioning & 9 & $\mathrm{FS}(16-23)=125$ \\
\hline & & & $\mathrm{FS}(17-23)=102$ \\
\hline & & & $\mathrm{FS}(18-23)=76$ \\
\hline & & & $\mathrm{FS}(19-23)=43$ \\
\hline & & & $\mathrm{FS}(20-23)=28$ \\
\hline & & & $\mathrm{FS}(21-23)=5$ \\
\hline 24 & Lighting Commisioning & 5 & $S S(23-24)=8$ \\
\hline 25 & System Control Commisioning & 5 & $\mathrm{FS}(24-25)=0$ \\
\hline \multirow[t]{3}{*}{26} & Harbour Acceptance Test & 32 & $\mathrm{FS}(22-26)=16$ \\
\hline & & & $\mathrm{FS}(23-26)=13$ \\
\hline & & & $\mathrm{FS}(25-26)=3$ \\
\hline 27 & Yard Trial & 15 & $S S(26-27)=26$ \\
\hline 28 & Delivery to Customer & 0 & $\mathrm{FS}(27-28)=2$ \\
\hline
\end{tabular}




\section{Determination of PDM-based Gantt Chart}

Determination of PDM-based Gantt Chart in

this thesis can be seen in Figure 9 below, which is where the Gantt Chart has the principle to describe work activities in graphical form with a timescale.

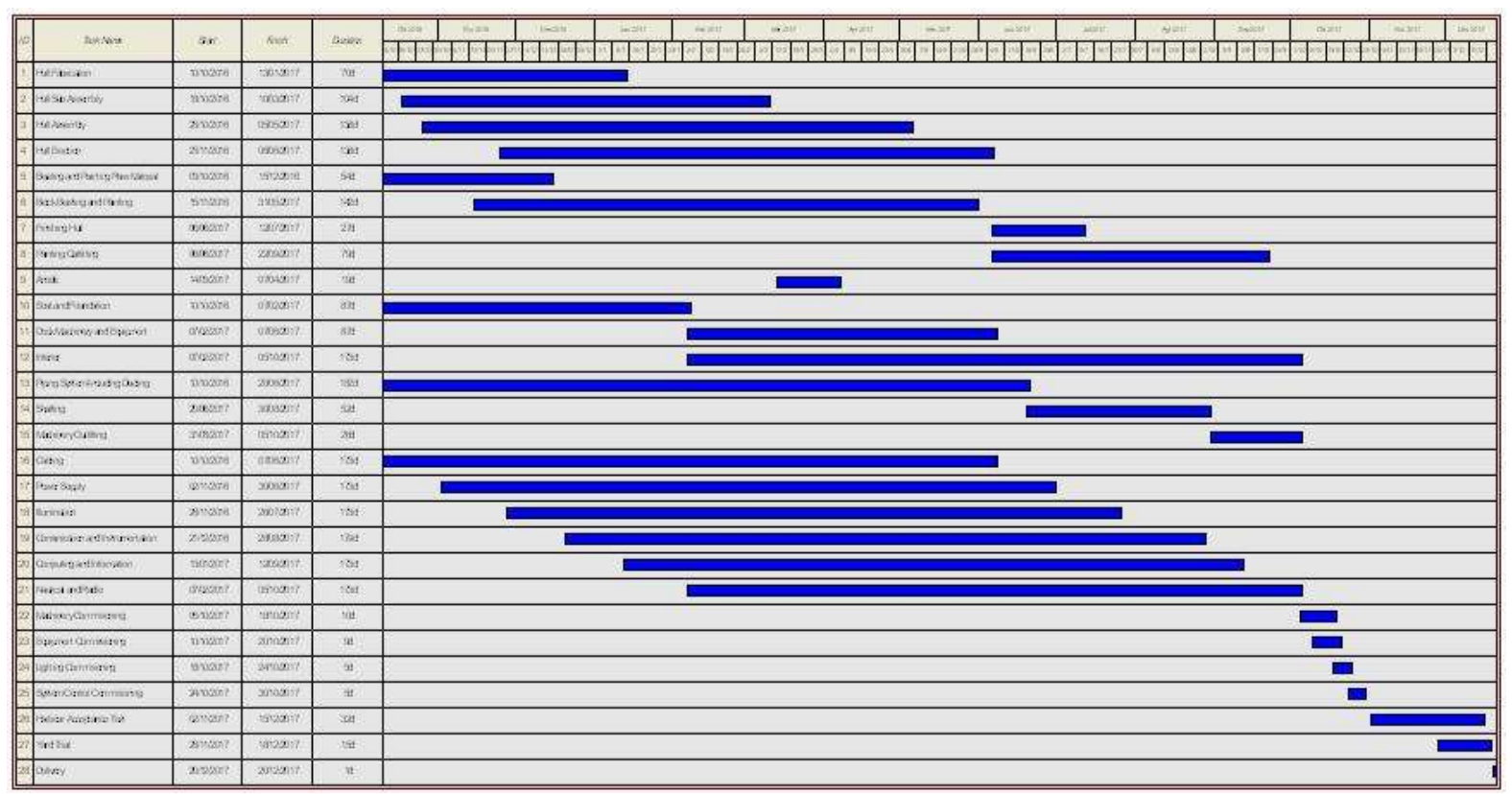

Fig. 9 Gantt Chart Planning Project for Missile Boat Construction (KCR-60) based on PDM

Determination of Time Schedule using PDM One of the important things in project

analysis is knowing when the project can be completed. The relationship with other activities and when the activity begins and ends. Precedence Diagram Method (PDM) is one of the scheduling techniques included in network planning scheduling techniques or network plans.

Before scheduling, a table of project activities is first prepared as listed in the following table:

Table 4.Table of Activities for Missile Boat (KCR-60) Construction Project

\begin{tabular}{|c|l|c|c|c|}
\hline No & \multicolumn{1}{|c|}{ Job Description } & $\begin{array}{c}\text { Activity } \\
\text { Code }\end{array}$ & Initial Activity & $\begin{array}{c}\text { Duratio } \\
\mathbf{n} \\
\text { (day) }\end{array}$ \\
\hline & Hull Construction & & & \\
\hline 1 & Hull Fabrication & 1 & - & 70 \\
\hline 2 & Hull Sub Assembly & 2 & 1 & 104 \\
\hline 3 & Hull Assembly & 3 & 2 & 138 \\
\hline 4 & Hull Erection & 4 & 3 & 138 \\
\hline & $\begin{array}{l}\text { Painting anode Cathodic } \\
\text { Protection }\end{array}$ & & & \\
\hline 5 & $\begin{array}{l}\text { Blasting and Painting Raw } \\
\text { Material }\end{array}$ & 5 & & 54 \\
\hline
\end{tabular}




\begin{tabular}{|c|c|c|c|c|}
\hline No & Job Description & $\begin{array}{l}\text { Activity } \\
\text { Code }\end{array}$ & Initial Activity & $\begin{array}{c}\text { Duratio } \\
\mathrm{n} \\
\text { (day) }\end{array}$ \\
\hline 6 & Block Blasting and Painting & 6 & 5 & 54 \\
\hline 7 & Finishing Hull & 7 & $3,4,6,9$ & 142 \\
\hline 8 & Painting Outfitting & 8 & 4,6 & 27 \\
\hline \multirow[t]{2}{*}{9} & Anodizing & 9 & 2 & 19 \\
\hline & Hull Outfitting & & & \\
\hline 10 & Seat and Foundation & 10 & 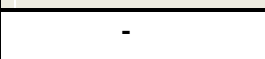 & 87 \\
\hline 11 & Deck Machinery and Equipment & 11 & 10 & 87 \\
\hline \multirow[t]{2}{*}{12} & Interior & 12 & 10 & 173 \\
\hline & Machinery Outfitting & & & \\
\hline 13 & Piping System Including Ducting & $\overline{13}$ & - & 182 \\
\hline 14 & Shafting & 14 & 11,13 & 52 \\
\hline \multirow[t]{2}{*}{15} & Machinery Outfitting & 15 & 7.8 .14 & 26 \\
\hline & Electric, Electronic Outfitting & & & \\
\hline 16 & Cabling & 16 & - & 173 \\
\hline 17 & Power Supply & 17 & 16 & 173 \\
\hline 18 & Illumination & 18 & 16 & 173 \\
\hline 19 & $\begin{array}{l}\text { Communication and } \\
\text { Instrumentation }\end{array}$ & 19 & 16 & 179 \\
\hline 20 & Computing and Information & 20 & 16 & 173 \\
\hline \multirow[t]{2}{*}{21} & Nautical and Radio & 21 & 16 & 173 \\
\hline & Function and Commisioning & & & \\
\hline 22 & Machinery Commisioning & 22 & 12,15 & 10 \\
\hline 23 & Equipment Commisioning & 23 & $\begin{array}{c}16,17,18,19,20 \\
21\end{array}$ & 9 \\
\hline 24 & Lighting commisioning & 24 & 23 & 5 \\
\hline \multirow[t]{2}{*}{25} & System Control Commisioning & 25 & 24 & 5 \\
\hline & HAT and SAT & & & \\
\hline 26 & Harbour Acceptance Test & 26 & $22,23,25$ & 32 \\
\hline \multirow[t]{2}{*}{27} & Yard Trial & 27 & 26 & 15 \\
\hline & Delivery & & & \\
\hline 28 & Delivery to Customer & 28 & 27 & 0 \\
\hline
\end{tabular}

To prepare a complete network, long processes and rules are needed. This begins with the technique of creating a network and ends with improving its quality. Regarding the terminology and basic rules of the work network, the most important are activities which are components of the project and dependency relationships with one another. Based on the series of project activities in the table above with the addition of constraints provisions in table 4 , they were then described in 
the form of a networking planning diagram using

as shown below:

activity signs in the activity on node (AON) model

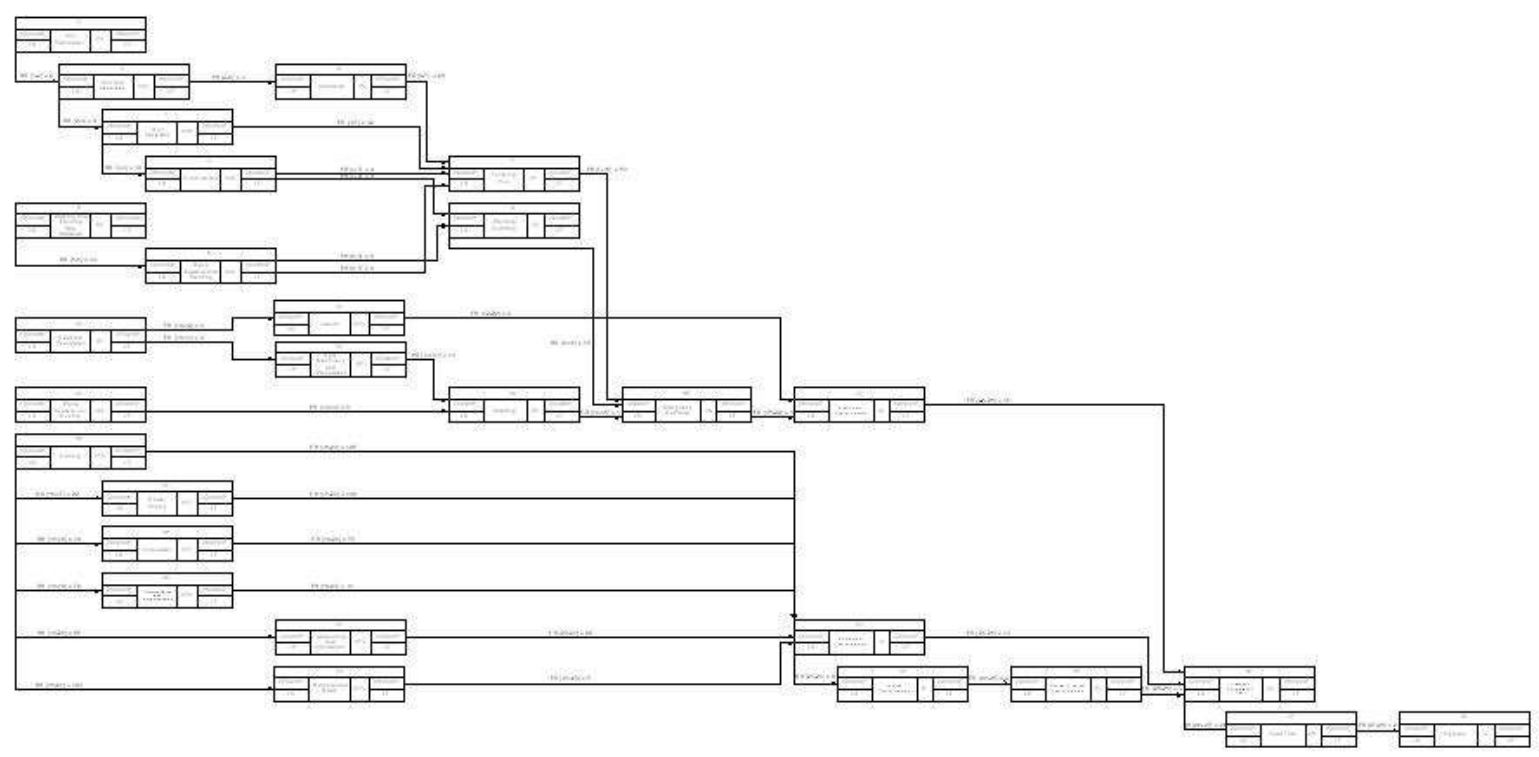

Fig. 10 Activity On Node Missile Boat (KCR-60) Construction Project

After the Time Schedule was known, the next step was the researcher performs the PDM calculation to find out the project completion time. There were two stages in the PDM, namely forward pass, which calculates the fastest occurrence of events and the quickest start and completion of activities and the backward pass to calculate when the latest activities start and finish at the latest.

Table 5. Recapitulation of Value Calculation of ES, EF, SL, LS, and LF Missile Boat (KCR-60) Construction Project

\begin{tabular}{|c|c|c|c|c|c|c|}
\hline Activity Code & $\begin{array}{c}\text { Duration } \\
\text { (Day) }\end{array}$ & ES & EF & SL & LS & LF \\
\hline $\mathbf{1}$ & $\mathbf{7 0}$ & $\mathbf{0}$ & $\mathbf{7 0}$ & $\mathbf{0}$ & $\mathbf{0}$ & $\mathbf{7 0}$ \\
\hline $\mathbf{2}$ & $\mathbf{1 0 4}$ & $\mathbf{8}$ & $\mathbf{1 1 2}$ & $\mathbf{0}$ & $\mathbf{8}$ & $\mathbf{1 1 2}$ \\
\hline $\mathbf{3}$ & $\mathbf{1 3 8}$ & $\mathbf{1 6}$ & $\mathbf{1 5 4}$ & $\mathbf{0}$ & $\mathbf{1 6}$ & $\mathbf{1 5 4}$ \\
\hline $\mathbf{4}$ & $\mathbf{1 3 8}$ & $\mathbf{4 6}$ & $\mathbf{1 9 2}$ & $\mathbf{0}$ & $\mathbf{4 6}$ & $\mathbf{1 9 2}$ \\
\hline $\mathbf{5}$ & $\mathbf{5 4}$ & $\mathbf{0}$ & $\mathbf{5 4}$ & $\mathbf{0}$ & $\mathbf{0}$ & $\mathbf{5 4}$ \\
\hline $\mathbf{6}$ & $\mathbf{1 4 2}$ & $\mathbf{4 0}$ & $\mathbf{1 8 6}$ & $\mathbf{0}$ & $\mathbf{4 0}$ & $\mathbf{1 8 6}$ \\
\hline 7 & 27 & 188 & 215 & 4 & 192 & 219 \\
\hline 8 & 79 & 188 & 267 & 5 & 193 & 272 \\
\hline 9 & 19 & 125 & 144 & 9 & 144 & 163 \\
\hline 10 & 87 & 0 & 87 & 29 & 29 & 122 \\
\hline 11 & 87 & 87 & 174 & 29 & 116 & 203 \\
\hline 12 & 173 & 87 & 260 & 35 & 122 & 295 \\
\hline 13 & 182 & 0 & 182 & 34 & 34 & 216 \\
\hline 14 & 52 & 187 & 239 & 29 & 216 & 268 \\
\hline 15 & 26 & 265 & 291 & 4 & 269 & 295 \\
\hline $\mathbf{1 6}$ & $\mathbf{1 7 3}$ & $\mathbf{0}$ & $\mathbf{1 7 3}$ & $\mathbf{0}$ & $\mathbf{0}$ & $\mathbf{1 7 3}$ \\
\hline 17 & 173 & 22 & 195 & 1 & 23 & 196 \\
\hline $\mathbf{1 8}$ & $\mathbf{1 7 3}$ & $\mathbf{4 9}$ & $\mathbf{2 2 2}$ & $\mathbf{0}$ & $\mathbf{4 9}$ & $\mathbf{2 2 2}$ \\
\hline 19 & 179 & 72 & 251 & 4 & 76 & 255 \\
\hline
\end{tabular}




\begin{tabular}{|c|c|c|c|c|c|c|}
\hline Activity Code & $\begin{array}{c}\text { Duration } \\
\text { (Day) }\end{array}$ & ES & EF & SL & LS & LF \\
\hline 20 & 173 & 95 & 268 & 2 & 97 & 270 \\
\hline $\mathbf{2 1}$ & $\mathbf{1 7 3}$ & $\mathbf{1 2 0}$ & $\mathbf{2 9 3}$ & $\mathbf{0}$ & $\mathbf{1 2 0}$ & $\mathbf{2 9 3}$ \\
\hline 22 & 10 & 291 & 301 & 4 & 295 & 305 \\
\hline $\mathbf{2 3}$ & $\mathbf{9}$ & $\mathbf{2 9 8}$ & $\mathbf{3 0 7}$ & $\mathbf{0}$ & $\mathbf{2 9 8}$ & $\mathbf{3 0 7}$ \\
\hline 24 & 5 & 306 & 311 & 1 & 307 & 312 \\
\hline 25 & 5 & 311 & 316 & 1 & 312 & 317 \\
\hline $\mathbf{2 6}$ & $\mathbf{3 2}$ & $\mathbf{3 2 1}$ & $\mathbf{3 5 2}$ & $\mathbf{0}$ & $\mathbf{3 2 0}$ & $\mathbf{3 5 2}$ \\
\hline $\mathbf{2 7}$ & $\mathbf{1 5}$ & $\mathbf{3 4 6}$ & $\mathbf{3 6 1}$ & $\mathbf{0}$ & $\mathbf{3 4 6}$ & $\mathbf{3 6 1}$ \\
\hline $\mathbf{2 8}$ & $\mathbf{0}$ & $\mathbf{3 6 3}$ & $\mathbf{3 6 3}$ & $\mathbf{0}$ & $\mathbf{3 6 3}$ & $\mathbf{3 6 3}$ \\
\hline
\end{tabular}

Based on Table 5, the critical path from the PDM calculation was obtained. The critical path is the path through which critical work passes, ie the work that has the earliest start time equals the last start time $(E S=L S)$ and the earliest completion time is the latest finish time $(E F=L F)$. The critical path on PDM can be seen in the following figure:

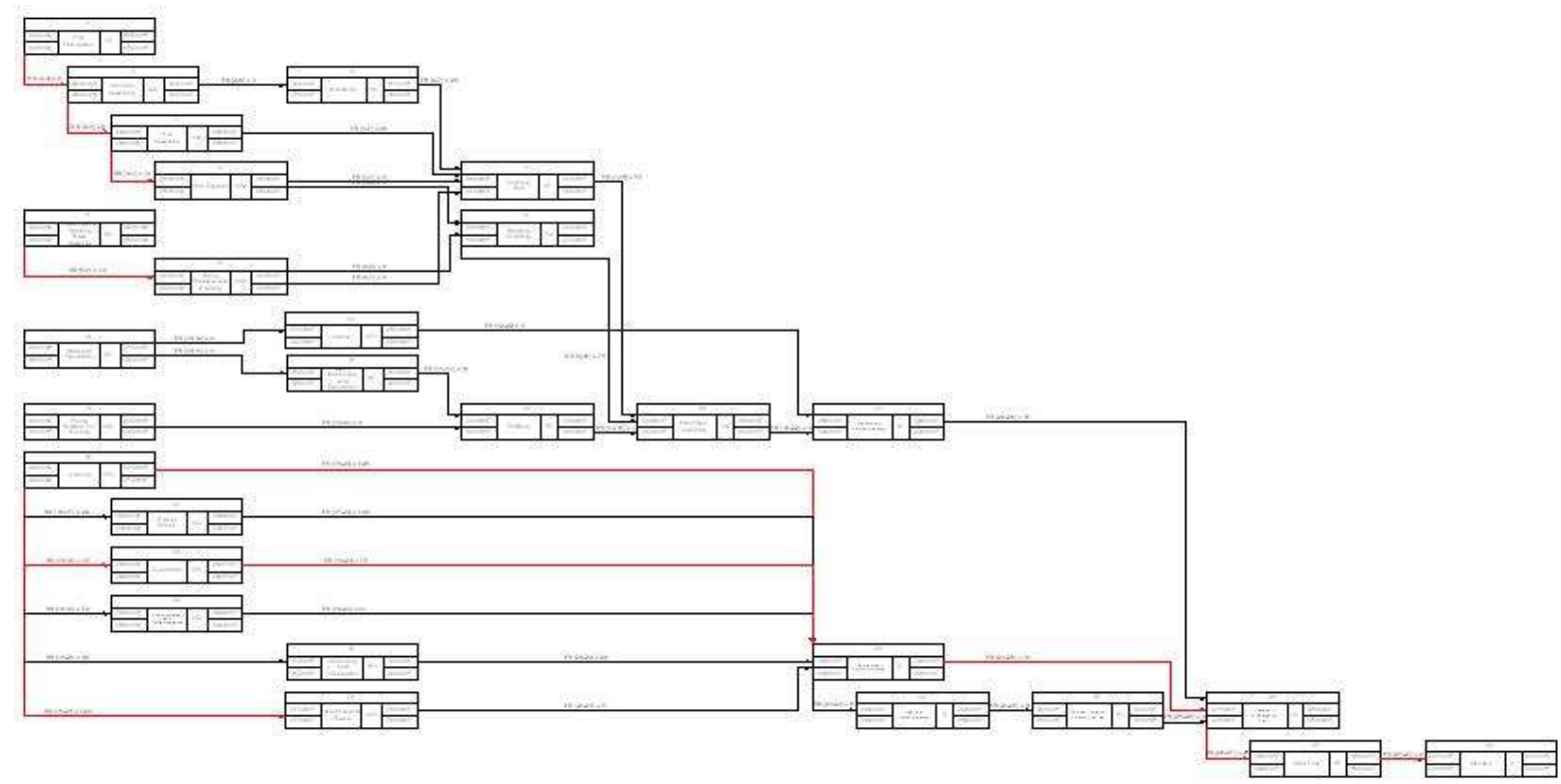

Fig. 11 PDM critical lane on Missile Boat (KCR-60) Construction Project

\section{Project Scheduling With Microsoft Project}

Microsoft Project is a computer program that assists in the preparation of planning and monitoring the schedule of a project, in which there is a detailed calculation of the project schedule for activities and recording, monitoring the use of resources, both in the form of human resources, equipment, and material.

The following are the results of project scheduling analysis using Microsoft Project 2010 software in the form of a network diagram and Gantt Chart as listed in the following picture: 


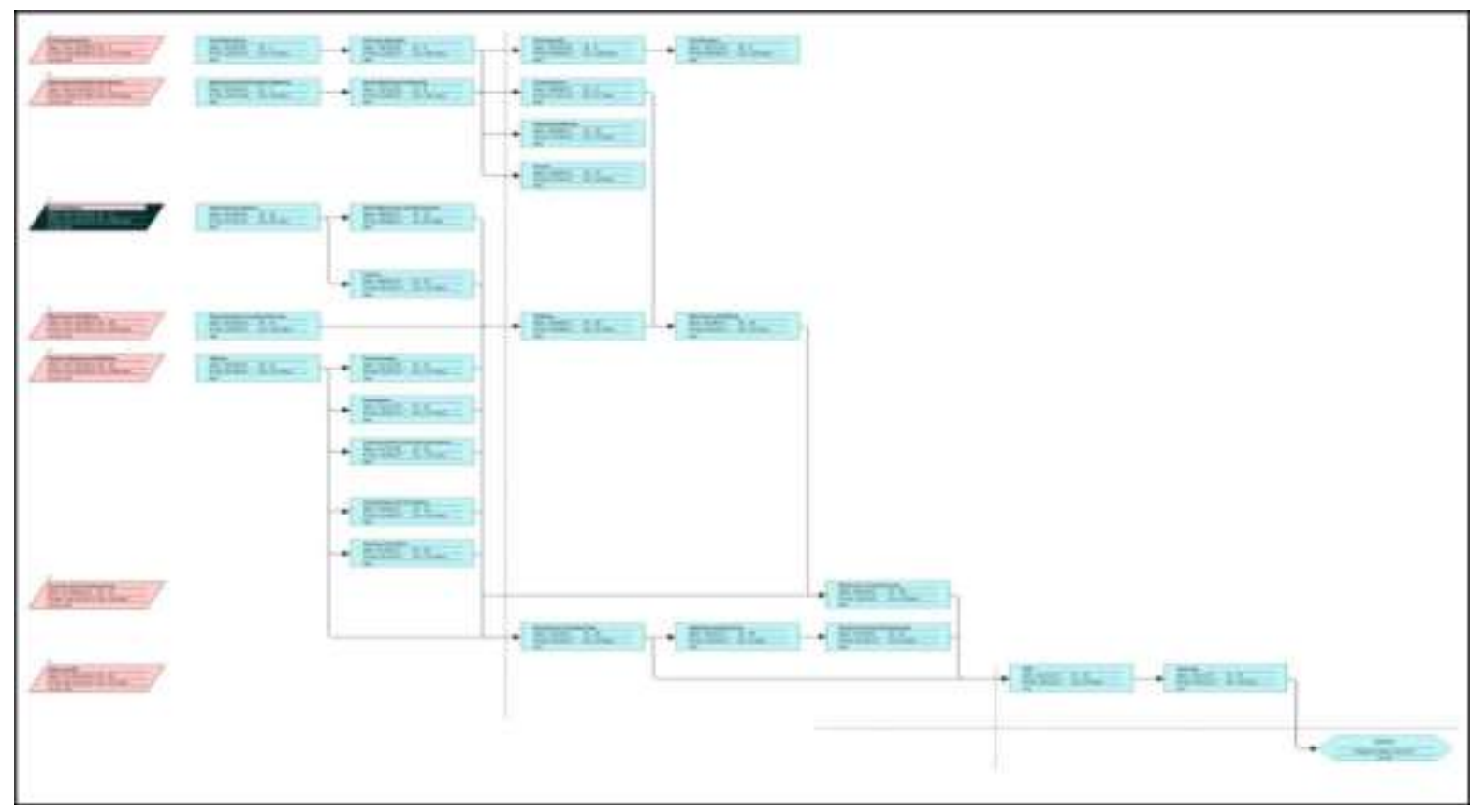

Fig.12 Network Diagram Output MS. Projection Construction Project of (KCR-60)

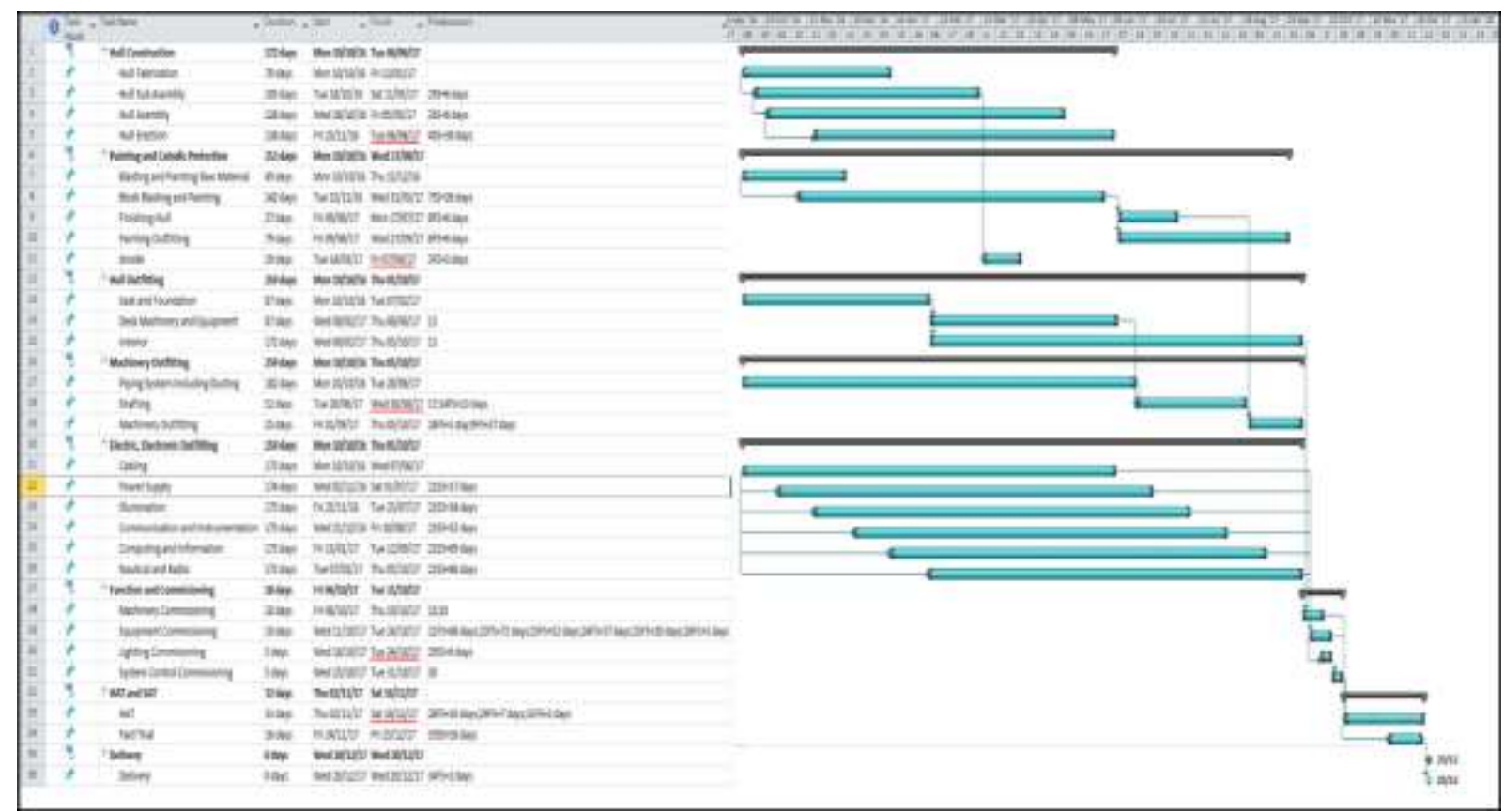

Fig. 13 Gantt Chart Output MS Projection Construction Project of (KCR-60)

\section{Calculation Earned Value Method (EVM)}

Calculation of Earned Value Method (EVM) on this project resulted in the value of the Budget Cost Work Schedule (BCWS), Budget CostWork
Performed (BCWP), Actual Cost Work Performed (ACWP), Cost Variance Analysis and Schedule Variance, along with Productivity and Performance Indexes. 


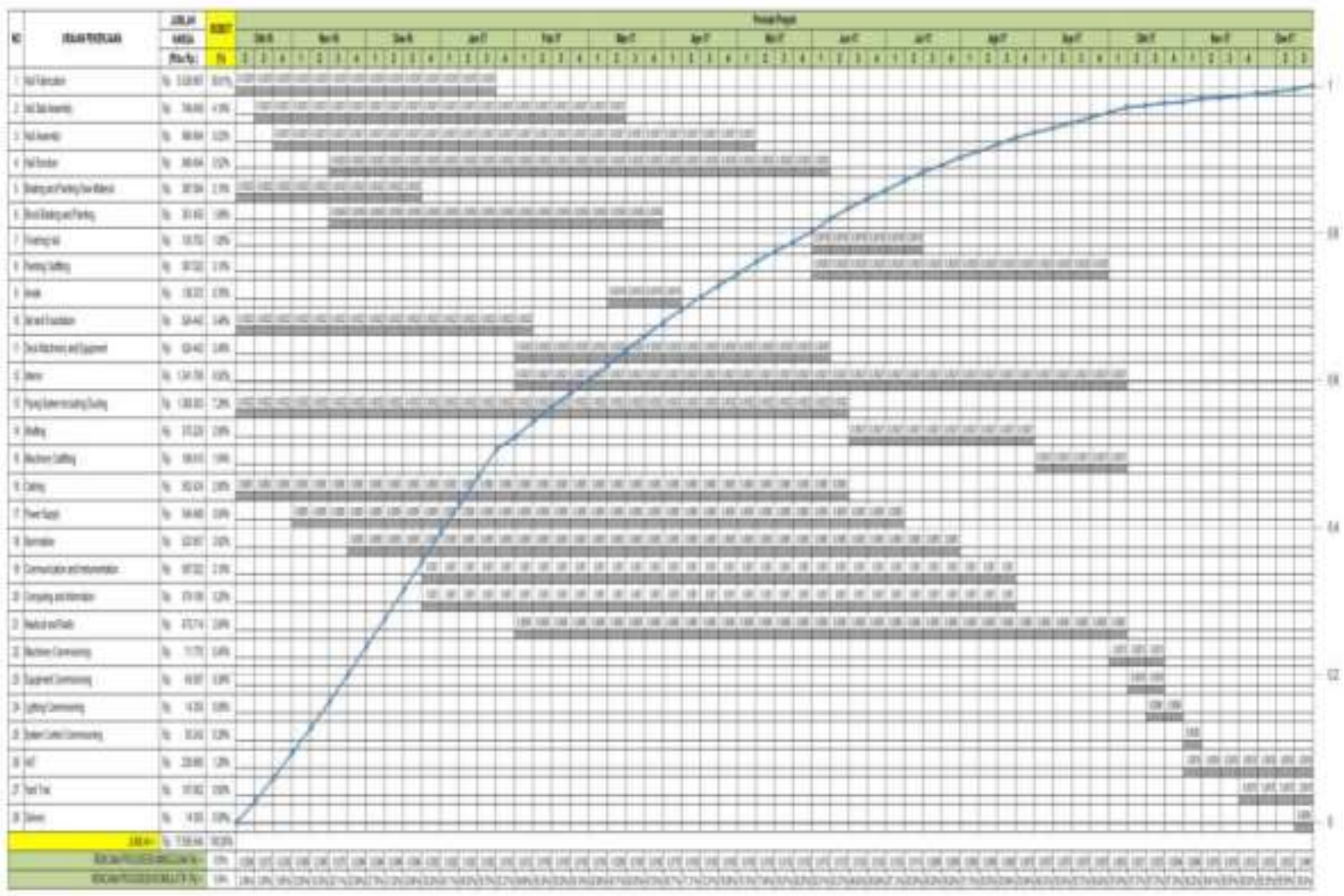

Fig. 14 S-Curve

The result of the S-curve drawing shows where at the end of the period the work progress that the completion of the project was completed is submitted to the Contractor as presented in the on the 363rd day. Because this project is already following table: underway, a project reporting period is created,

Table 6. Project Planning Period Date

\begin{tabular}{|c|c|c|c|}
\hline Period & Day & Date Period & Plan Weight \\
\hline 1 & 16 & 10 Oct 16 - 31 Oct 16 & $9,45 \%$ \\
\hline 2 & 38 & 1 Nov 16-30 Nov 16 & $14,50 \%$ \\
\hline 3 & 60 & 1 Dec 16-31 Dec 16 & $15,34 \%$ \\
\hline 4 & 82 & 1 Jan 16-31 Jan 17 & $13,09 \%$ \\
\hline 5 & 102 & 1 Feb 17-28 Feb 17 & $7,81 \%$ \\
\hline 6 & 125 & 1 Mar 17-31 Mar 17 & $7,75 \%$ \\
\hline 7 & 145 & 1 Apr 17-30 Apr 17 & $6,58 \%$ \\
\hline 8 & 168 & 1 May 17-31 May 17 & $5,75 \%$ \\
\hline 9 & 190 & 1 Jun 17-30 Jun 17 & $5,62 \%$ \\
\hline 10 & 223 & 1 Jul 17-31 Jul 17 & $4,38 \%$ \\
\hline 11 & 244 & 1 August 17 -31 Agust 17 & $3,38 \%$ \\
\hline 12 & 262 & 1 Sep 17-30 Sep 17 & $2,78 \%$ \\
\hline 13 & 301 & 1 Oct 17-31 Oct 17 & $1,34 \%$ \\
\hline 14 & 342 & 1 Nov 14-31 Nov 17 & $1,16 \%$ \\
\hline 15 & 363 & 1 Dec 17-20 Dec 17 & $1,08 \%$ \\
\hline
\end{tabular}

Table 7. BCWS Recapitulation

\begin{tabular}{|c|c|cc|cc|}
\hline Period & Plan Weight & \multicolumn{2}{c|}{ BCWS } & \multicolumn{2}{c|}{ BCWS Cumulative } \\
\hline 1 & $9,45 \%$ & $\mathrm{Rp}$ & 1.694 .815 .426 & $\mathrm{Rp}$ & 1.694 .815 .426 \\
\hline 2 & $14,50 \%$ & $\mathrm{Rp}$ & 2.599 .969 .130 & $\mathrm{Rp}$ & 4.294 .784 .556 \\
\hline
\end{tabular}




\begin{tabular}{|c|c|cc|c|}
\hline Period & Plan Weight & & BCWS & BCWS Cumulative \\
\hline 3 & $15,34 \%$ & $\mathrm{Rp}$ & 2.751 .371 .109 & $\mathrm{Rp} 7.046 .155 .666$ \\
\hline 4 & $13,09 \%$ & $\mathrm{Rp}$ & 2.347 .323 .316 & $\mathrm{Rp} 9.393 .478 .981$ \\
\hline 5 & $7,81 \%$ & $\mathrm{Rp}$ & 1.400 .811 .892 & $\mathrm{Rp} 10.794 .290 .874$ \\
\hline 6 & $7,75 \%$ & $\mathrm{Rp}$ & 1.389 .417 .628 & $\mathrm{Rp} 12.183 .708 .501$ \\
\hline 7 & $6,58 \%$ & $\mathrm{Rp}$ & 1.179 .595 .688 & $\mathrm{Rp} 13.363 .304 .189$ \\
\hline 8 & $5,75 \%$ & $\mathrm{Rp}$ & 1.031 .214 .898 & $\mathrm{Rp} 14.394 .519 .087$ \\
\hline 9 & $5,62 \%$ & $\mathrm{Rp}$ & 1.008 .844 .859 & $\mathrm{Rp} 15.403 .363 .946$ \\
\hline 10 & $4,38 \%$ & $\mathrm{Rp}$ & 786.266 .776 & $\mathrm{Rp} 16.189 .630 .722$ \\
\hline 11 & $3,38 \%$ & $\mathrm{Rp}$ & 605.966 .339 & $\mathrm{Rp} 16.795 .597 .061$ \\
\hline 12 & $2,78 \%$ & $\mathrm{Rp}$ & 498.976 .888 & $\mathrm{Rp} 17.294 .573 .948$ \\
\hline 13 & $1,34 \%$ & $\mathrm{Rp}$ & 240.032 .645 & $\mathrm{Rp} 17.534 .606 .594$ \\
\hline 14 & $1,16 \%$ & $\mathrm{Rp}$ & 208.403 .531 & $\mathrm{Rp} 17.743 .010 .125$ \\
\hline 15 & $1,08 \%$ & $\mathrm{Rp}$ & 193.535 .875 & $\mathrm{Rp} 17.936 .546 .000$ \\
\hline
\end{tabular}

Table 8. BCWP Recapitulation

\begin{tabular}{|c|c|c|cc|cr|}
\hline Period & Realization & $\begin{array}{l}\text { Cumulative } \\
\text { Realization }\end{array}$ & \multicolumn{1}{|c|}{ BCWP } & \multicolumn{2}{|c|}{ BCWP Cumulative } \\
\hline 1 & $7,98 \%$ & $7,98 \%$ & $\mathrm{Rp} 1.432 .119 .035$ & $\mathrm{Rp}$ & 1.432 .119 .035 \\
\hline 2 & $12,86 \%$ & $20,84 \%$ & $\mathrm{Rp} 2.306 .172 .618$ & $\mathrm{Rp}$ & 3.738 .291 .653 \\
\hline 3 & $13,15 \%$ & $33,99 \%$ & $\mathrm{Rp} 2.357 .925 .041$ & $\mathrm{Rp}$ & 6.096 .216 .694 \\
\hline 4 & $11,80 \%$ & $45,79 \%$ & $\mathrm{Rp} 2.117 .285 .631$ & $\mathrm{Rp}$ & 8.213 .502 .325 \\
\hline 5 & $7,02 \%$ & $52,81 \%$ & $\mathrm{Rp} 1.259 .329 .891$ & $\mathrm{Rp}$ & 9.472 .832 .216 \\
\hline 6 & $6,11 \%$ & $58,92 \%$ & $\mathrm{Rp} 1.096 .250 .508$ & $\mathrm{Rp}$ & 10.569 .082 .725 \\
\hline 7 & $5,84 \%$ & $64,76 \%$ & $\mathrm{Rp}$ & 1.047 .480 .971 & $\mathrm{Rp}$ & 11.616 .563 .695 \\
\hline 8 & $4,39 \%$ & $69,16 \%$ & $\mathrm{Rp}$ & 787.848 .182 & $\mathrm{Rp}$ & 12.404 .411 .877 \\
\hline 9 & $4,46 \%$ & $73,62 \%$ & $\mathrm{Rp}$ & 800.013 .973 & $\mathrm{Rp}$ & 13.204 .425 .850 \\
\hline 10 & $3,20 \%$ & $76,82 \%$ & $\mathrm{Rp}$ & 574.761 .013 & $\mathrm{Rp}$ & 13.779 .186 .863 \\
\hline 11 & $2,93 \%$ & $79,75 \%$ & $\mathrm{Rp}$ & 525.372 .816 & $\mathrm{Rp}$ & 14.304 .559 .679 \\
\hline 12 & $2,54 \%$ & $82,29 \%$ & $\mathrm{Rp}$ & 456.064 .875 & $\mathrm{Rp}$ & 14.760 .624 .555 \\
\hline 13 & $1,25 \%$ & $83,55 \%$ & $\mathrm{Rp}$ & 224.670 .556 & $\mathrm{Rp}$ & 14.985 .295 .111 \\
\hline 14 & $1,02 \%$ & $84,57 \%$ & $\mathrm{Rp}$ & 183.186 .704 & $\mathrm{Rp}$ & 15.168 .481 .815 \\
\hline 15 & $0,79 \%$ & $85,36 \%$ & $\mathrm{Rp}$ & 141.861 .796 & $\mathrm{Rp}$ & 15.310 .343 .611 \\
\hline 16 & $7,40 \%$ & $92,76 \%$ & $\mathrm{Rp} 1.327 .304 .404$ & $\mathrm{Rp}$ & 16.637 .648 .015 \\
\hline 17 & $3,10 \%$ & $95,86 \%$ & $\mathrm{Rp}$ & 556.032 .926 & $\mathrm{Rp}$ & 17.193 .680 .941 \\
\hline 18 & $4,14 \%$ & $100,00 \%$ & $\mathrm{Rp}$ & 742.573 .004 & $\mathrm{Rp}$ & 17.936 .546 .000 \\
\hline
\end{tabular}

Table 9. ACWP Recapitulation

\begin{tabular}{|c|c|c|}
\hline Period & ACWP & ACWP Cumulative \\
\hline 1 & Rp1.575.330.939 & Rp 1.575.330.939 \\
\hline 2 & $\mathrm{Rp} 2.582 .913 .332$ & $\mathrm{Rp} \mathrm{4.158.244.271}$ \\
\hline 3 & $\mathrm{Rp} 2.711 .613 .797$ & $\mathrm{Rp} \mathrm{6.869.858.068}$ \\
\hline 4 & $\mathrm{Rp} 2.413 .705 .619$ & $\mathrm{Rp} \mathrm{9.283.563.687}$ \\
\hline 5 & $\mathrm{Rp} 1.410 .449 .478$ & $\mathrm{Rp} 10.694 .013 .165$ \\
\hline 6 & $\mathrm{Rp} 1.326 .463 .115$ & $\mathrm{Rp} 12.020 .476 .280$ \\
\hline 7 & $\mathrm{Rp} 1.152 .229 .068$ & $\mathrm{Rp} 13.172 .705 .348$ \\
\hline 8 & $\mathrm{Rp} 882.389 .964$ & $\mathrm{Rp} 14.055 .095 .312$ \\
\hline 9 & $\mathrm{Rp} 904.015 .789$ & $\mathrm{Rp} 14.959 .111 .101$ \\
\hline 10 & $\mathrm{Rp} 678.217 .996$ & $\mathrm{Rp} 15.637 .329 .097$ \\
\hline 11 & $\mathrm{Rp} 619.939 .923$ & $\mathrm{Rp} 16.257 .269 .020$ \\
\hline
\end{tabular}




\begin{tabular}{l|lll|}
\hline 12 & $\mathrm{Rp} 533.595 .904$ & $\mathrm{Rp} 16.790 .864 .924$ \\
\hline 13 & $\mathrm{Rp} 251.631 .023$ & $\mathrm{Rp} 17.042 .495 .947$ \\
\hline 14 & $\mathrm{Rp} 214.328 .444$ & $\mathrm{Rp} 17.256 .824 .391$ \\
\hline 15 & $\mathrm{Rp} 158.885 .212$ & $\mathrm{Rp} 17.415 .709 .602$ \\
\hline 16 & $\mathrm{Rp} 1.499 .853 .977$ & $\mathrm{Rp} 18.915 .563 .579$ \\
\hline 17 & $\mathrm{Rp} 644.998 .194$ & $\mathrm{Rp} 19.560 .561 .773$ \\
\hline 18 & $\mathrm{Rp} 846.533 .225$ & $\mathrm{Rp} 20.407 .094 .998$ \\
\hline
\end{tabular}

Table 10. Calculation of Cost Varians dan Schedule Varians

\begin{tabular}{|c|c|c|}
\hline Period & Cost Variant & Schedule Variant \\
\hline 1 & -Rp143.211.904 & -Rp 262.696.391 \\
\hline 2 & -Rp276.740.714 & -Rp 293.796.512 \\
\hline 3 & -Rp353.688.756 & $-\operatorname{Rp} 393.446 .069$ \\
\hline 4 & -Rp296.419.988 & -Rp 230.037.685 \\
\hline 5 & -Rp151.119.587 & -Rp 141.482.001 \\
\hline 6 & -Rp230.212.607 & -Rp 293.167.119 \\
\hline 7 & -Rp104.748.097 & -Rp 132.114.717 \\
\hline 8 & -Rp 94.541 .782 & -Rp 243.366.716 \\
\hline 9 & -Rp104.001.816 & -Rp 208.830.886 \\
\hline 10 & -Rp103.456.982 & -Rp 211.505.763 \\
\hline 11 & -Rp 94.567.107 & $\begin{array}{ll}-R p & 80.593 .523\end{array}$ \\
\hline 12 & $-\operatorname{Rp} 77.531 .029$ & -Rp 42.912 .012 \\
\hline 13 & -Rp 26.960.467 & -Rp 15.362 .089 \\
\hline 14 & $-\operatorname{Rp} 31.141 .740$ & 25.216 .827 \\
\hline 15 & -Rp 17.023.416 & 51.674 .079 \\
\hline 16 & -Rp172.549.573 & \\
\hline 17 & -Rp 88.965.268 & \\
\hline 18 & -Rp103.960.221 & \\
\hline
\end{tabular}

Table 11. Value of Project Performance in CPI and SPI

\begin{tabular}{|c|c|c|c|}
\hline Period & CPI & SPI & Information \\
\hline 1 & 0,91 & 0,85 & Cost overrun \& Schedule overrun \\
\hline 2 & 0,90 & 0,87 & Cost overrun \& Schedule overrun \\
\hline 3 & 0,89 & 0,87 & Cost overrun \& Schedule overrun \\
\hline 4 & 0,88 & 0,87 & Cost overrun \& Schedule overrun \\
\hline 5 & 0,89 & 0,88 & Cost overrun \& Schedule overrun \\
\hline 6 & 0,88 & 0,87 & Cost overrun \& Schedule overrun \\
\hline 7 & 0,88 & 0,87 & Cost overrun \& Schedule overrun \\
\hline 8 & 0,88 & 0,86 & Cost overrun \& Schedule overrun \\
\hline 9 & 0,88 & 0,86 & Cost overrun \& Schedule overrun \\
\hline 10 & 0,88 & 0,85 & Cost overrun \& Schedule overrun \\
\hline 11 & 0,88 & 0,85 & Cost overrun \& Schedule overrun \\
\hline 12 & 0,88 & 0,85 & Cost overrun \& Schedule overrun \\
\hline 13 & 0,88 & 0,85 & Cost overrun \& Schedule overrun \\
\hline 14 & 0,88 & 0,85 & Cost overrun \& Schedule overrun \\
\hline 15 & 0,88 & 0,85 & Cost overrun \& Schedule overrun \\
\hline 16 & 0,88 & 0,93 & Cost overrun \& Schedule overrun \\
\hline 17 & 0,88 & 0,96 & Cost overrun \& Schedule overrun \\
\hline 18 & 0,88 & 1,00 & Cost overrun \& Schedule overrun \\
\hline
\end{tabular}




\section{Acceleration of Project Completion Time (Crashing Project)}

Based on the PDM calculation, the addition of work time or overtime applies to all work activities, especially in activities that have a critical path, namely activities $1,2,3,4,5,6,16,18,21$, $23,26,27,28$. Based on the regulation of the Minister of Labor Number KEP.102/ MEN /VI/2004 contained in article 11, That working hours in a day have 8 normal working hours, namely $08.00-12.00$ WIB, 13.00-17.00 WIB and 1 hour break. If daily overtime work is held for a maximum of 3 hours, starting from 17.00-20.00 WIB, overtime wages are calculated every working day according to the occupation position of each worker. The following tabulation of the calculation of the duration after 1 hour overtime is carried out for all activities.

Table 12. Calculation of Work After OvertimeDuration

\begin{tabular}{|c|c|c|c|}
\hline Activity & $\begin{array}{c}\text { Plan } \\
\text { Duration }\end{array}$ & $\begin{array}{c}\text { Implementation } \\
\text { Duration }\end{array}$ & $\begin{array}{r}\text { Duration of } 1 \\
\text { hour overtime }\end{array}$ \\
\hline Hull Fabrication & 70 & 75 & 67 \\
\hline Hull Sub Assembly & 104 & 113 & 102 \\
\hline Hull Assembly & 138 & 153 & 138 \\
\hline Hull Erection & 138 & 153 & 137 \\
\hline Blasting and Painting Raw Material & 54 & 57 & 51 \\
\hline Block Blasting and Painting & 54 & 59 & 53 \\
\hline Finishing Hull & 142 & 145 & 131 \\
\hline Painting Outfitting & 27 & 28 & 25 \\
\hline Anode & 19 & 20 & 18 \\
\hline Seat and Foundation & 87 & 93 & 84 \\
\hline Deck Machinery and Equipment & 87 & 92 & 83 \\
\hline Interior & 173 & 186 & 167 \\
\hline Piping System Including Ducting & 182 & 204 & 182 \\
\hline Shafting & 52 & 53 & 48 \\
\hline Machinery Outfitting & 26 & 27 & 24 \\
\hline Cabling & 173 & 194 & 173 \\
\hline Power Supply & 173 & 194 & 173 \\
\hline Illumination & 173 & 194 & 173 \\
\hline Communication and Instrumentation & 179 & 198 & 178 \\
\hline Computing and Information & 173 & 188 & 169 \\
\hline Nautical and Radio & 173 & 186 & 167 \\
\hline Machinery Commisioning & 10 & 10 & - \\
\hline Equipment Commisioning & 9 & 9 & - \\
\hline Lighting commisioning & 5 & 5 & - \\
\hline System Control Commisioning & 5 & 5 & - \\
\hline Harbors Acceptance Test & 32 & 32 & - \\
\hline Yard Trial & 15 & 15 & - \\
\hline Delivery to Customer & 0 & 0 & - \\
\hline
\end{tabular}


Table 13. Daily Overtime Wages

\begin{tabular}{|c|c|c|c|c|}
\hline No. & Type of Worker & Hour & $\begin{array}{c}\text { Overtime } \\
\text { Wages of 1 hour }\end{array}$ & $\begin{array}{c}\text { Overtime wages } \\
\text { of 2 hours etc }\end{array}$ \\
\hline 1 & $\begin{array}{c}\text { Head of } \\
\text { Fabrication }\end{array}$ & $\operatorname{Rp~28.038}$ & $\operatorname{Rp~42.057}$ & $\operatorname{Rp~} 56.076$ \\
\hline 2 & Group Leader & $\operatorname{Rp~24.230}$ & $\operatorname{Rp~36.346}$ & $\operatorname{Rp~} 48.452$ \\
\hline 3 & Technician & $\operatorname{Rp~20.200~}$ & $\operatorname{Rp~30.300~}$ & $\operatorname{Rp~} 43.400$ \\
\hline 4 & Workman & $\operatorname{Rp~17.064}$ & $\operatorname{Rp~25.596}$ & $\operatorname{Rp~34.128}$ \\
\hline
\end{tabular}

Table 14. Calculation of Overtime Labor Costs

\begin{tabular}{|c|c|c|c|c|c|c|}
\hline \multirow[b]{2}{*}{ Activity } & \multirow{2}{*}{$\begin{array}{l}\text { Overtime } \\
\text { Hour }\end{array}$} & \multicolumn{4}{|c|}{ The amount of Labor } & \multirow{2}{*}{$\begin{array}{c}\text { Overtime } \\
\text { Wages }\end{array}$} \\
\hline & & $\begin{array}{c}\text { Head of } \\
\text { Fabrication }\end{array}$ & Group Leader & Technician & Workman & \\
\hline Hull Fabrication & 70 & 1 & 1 & 3 & 5 & $R p 20.809 .810$ \\
\hline $\begin{array}{l}\text { Hull Sub } \\
\text { Assembly }\end{array}$ & 104 & 0 & 0 & 0 & 5 & Rp 13.309 .920 \\
\hline Hull Assembly & 138 & 0 & 0 & 3 & 5 & $\operatorname{Rp} 30.205 .440$ \\
\hline Hull Erection & 138 & 0 & 0 & 3 & 6 & $\operatorname{Rp} 33.737 .688$ \\
\hline $\begin{array}{c}\text { Blasting and } \\
\text { Painting Raw } \\
\text { Material }\end{array}$ & 54 & 1 & 1 & 1 & 4 & Rp 11.398.698 \\
\hline $\begin{array}{c}\text { Block Blasting and } \\
\text { Painting }\end{array}$ & 54 & 0 & 0 & 1 & 3 & Rp 5.782.752 \\
\hline Finishing Hull & 142 & 0 & 0 & 2 & 6 & Rp 30.412.992 \\
\hline Painting Outfitting & 27 & 0 & 0 & 1 & 6 & Rp 4.964.652 \\
\hline Anode & 19 & 0 & 0 & 1 & 5 & Rp 3.007.320 \\
\hline $\begin{array}{l}\text { Seat and } \\
\text { Foundation }\end{array}$ & 87 & 1 & 1 & 2 & 5 & Rp 23.227.521 \\
\hline $\begin{array}{l}\text { Deck Machinery } \\
\text { and Equipment }\end{array}$ & 87 & 0 & 0 & 2 & 6 & Rp 18.633.312 \\
\hline Interior & 173 & 0 & 0 & 2 & 8 & Rp 45.908.664 \\
\hline $\begin{array}{c}\text { Piping System } \\
\text { Including Ducting }\end{array}$ & 182 & 1 & 1 & 1 & 7 & Rp 52.393.250 \\
\hline Shafting & 52 & 0 & 0 & 2 & 4 & $\operatorname{Rp} 8.475 .168$ \\
\hline $\begin{array}{l}\text { Machinery } \\
\text { Outfitting }\end{array}$ & 26 & 0 & 0 & 1 & 5 & Rp 4.115.280 \\
\hline Cabling & 173 & 1 & 1 & 2 & 4 & Rp 41.759.951 \\
\hline Power Supply & 173 & 0 & 0 & 2 & 4 & $\mathrm{Rp} 28.196 .232$ \\
\hline Illumination & 173 & 0 & 0 & 1 & 4 & Rp 22.954.332 \\
\hline $\begin{array}{l}\text { Communication } \\
\text { and } \\
\text { Instrumentation }\end{array}$ & 179 & 0 & 0 & 1 & 4 & Rp 23.750.436 \\
\hline $\begin{array}{l}\text { Computing and } \\
\text { Information }\end{array}$ & 173 & 0 & 0 & 1 & 4 & Rp 22.954.332 \\
\hline $\begin{array}{l}\text { Nautical and } \\
\text { Radio }\end{array}$ & 173 & 0 & 0 & 2 & 4 & Rp 28.196.232 \\
\hline & & Total & & & & $\begin{array}{l}\text { Rp } \\
474.193 .982\end{array}$ \\
\hline
\end{tabular}




\section{CONCLUSION.}

Based on the calculations, it was found that activity $1,2,3,4,5,6,16,18,21,23,26,27,28$ are critical paths. With the Crashing Project which was originally 414 days from the end of the real work job to 363 days, resulted in 51 days of effectiveness. Meanwhile for cost efficiency, based on the analysis of the real cost of project implementation,
Rp. 20.407,094,998, - became Rp. 18,410,738,982, so there are of Rp. $2,470,548,998$, - of efficiency. Thus, control and supervision of the contractor are required in every activity in carrying out the activities of the Missile Boat (KCR-60) construction project so that it does not experience delays and the project can be completed on time.

Table 15. Simulation of Project Time and Costs (KCR-60)

\begin{tabular}{|c|c|c|c|}
\hline & Contract & PDM-EVM-Crash Project & Real Implementation \\
\hline Time & 363 day & 363 day & 414 day \\
\hline Cost & Rp. 17.936 .546 .000 & Rp. 18.410 .739 .982 & Rp. 20.407 .094 .998 \\
\hline
\end{tabular}

\section{ACKNOWLEDGEMENTS.}

This research has been Supported by Indonesia Naval Technology College (STTAL).

\section{BIBLIOGRAPHY.}

Agarwal, R. (2013) 'Critical Path Method in Designing Feasible Solutions', International Journal of Scientific Research and Reviews, pp. 190-202.

Agyei, W. (2015) 'Project Planning And Scheduling Using PERT And CPM Techniques With Linear Programming: Case Study', INTERNATIONAL JOURNAL OF SCIENTIFIC \& TECHNOLOGY RESEARCH, pp. 222-227.

Alecu, F. (2014) 'Cost Control and Performance Review of Software Projects by Using the Earned Value Management', Oeconomics of Knowledge, pp. 2-6.

Andawei, M.-E.M. (2014) 'Extension of Time Determination in Construction Projects in Nigeria: The Critical Path Method', The International Journal Of Engineering And Science (IJES), pp. 48-51.
Arica Dwi Susanto, A.A.O.S.S. (2018) 'The Optimization of Multipurpose Building Development on Project Scheduling Using Precedence Diagram Method (PDM)', ASRO JOURNAL-STTAL, vol. 9, no. 1, pp. 1-7.

Balla, G.T. (1995) 'Critical path analysis for the management of fractured neck of femur', AUSTRALIAN JOURNAL OF PUBLIC HEALTH, pp. 155-159.

Czarnigowska, A. (2008) 'Earned value method as a tool for project control ', Budownictwo $i$ Architektura 3, pp. 15-32.

Daniel Castro-Lacouture, A.M.A.G.A.S.J.G.J.a.J.K.Y. (2009) 'Contruction Project Scheduling with Time, Cost and Material Restrictions Using Fuzzy Mathematical Models and Critical Path Method ', JOURNAL OF CONSTRUCTION ENGINEERING AND MANAGEMENT, pp. 10961104. 
Dwaikat, L.N. (2016) 'Measuring the Actual Energy Cost Performance of Green Buildings: A Test of the Earned Value Management Approach', Energies journal, pp. 1-20.

Fatemeh Nouban, N.G. (2017) 'The Factors Affecting The Methods of Construction Projects Scheduling: An State of The Art and Overview', Asian Journal of Natural \& Applied Sciences, vol. 6, no. 4, pp. 114-122.

K.K.Khandelwal, D.B. (2002) PROJECT PLANNING AND CONTROL WITH PERT AND CPM, New Delhi: LAXMI PUBLICATIONS (P) LTD. Kim, S.-G. (2012) 'CPM Schedule Summarizing Function of the Beeline Diagram Method', Journal of Asian Architecture and Building Engineering, pp. 367-374.

M, S. (2015) 'Traditional Critical Path Method versus Critical Chain Project Management: A Comparative View', International Journal of Economics \& Management Sciences, pp. 1-6.

Mazlum, M. (2015) 'CPM, PERT and Project Management With Fuzzy Logic Technique and Implementation On A Business', 4th International Conference on Leadership, Technology, Innovation and Business Management, Istanbul, 348-357.

Nafkha, R. (2016) 'THE CRITICAL PATH METHOD IN ESTIMATING PROJECT DURATION', Information Systems in Management, pp. 78-87.

R.Lin, H.J. (2009) 'A fuzzy pert approach to evaluate plant construction project scheduling risk under uncertain resources capacity', Journal of
Industrial Engineering and Management, pp. 3147.

Shailla (2014) 'Comparative Study of Management Operation System Techniques (MOST) and CPM in Construction Scheduling', International Journal of Engineering Trends and Technology (IJETT), pp. 371-379.

Shan, Y. (2014) 'Integration of Building Information Modeling and Critical Path Method Schedules to Simulate the Impact of Temperature and Humidity at the Project Level', buildings jounal, pp. 295-319.

Silvianita, R.F.D.M.R.S.a.D.M.C. (2018) 'Fast Missile Boat Project Planning using CPM and What If Analysis Method', IOP Conf. Series: Earth and Environmental Science, jakarta, 1-6.

Wilson, B. (2013) 'Earned Value Management Systems: Challenges and Future Direction', Journal of Integrated Enterprise Systems, pp. 9-17.

Wong, Y. (1964) 'Critical Path Analysis for New Product Planning', Journal of Marketing, pp. 53-59. Y. Arslan, H.B.M.E. (2017) 'Planning and Monitoring of industrial punch development processes ', Journal of Engineering Research and Applied Science, pp. 615-622. 